\title{
(Un)grounding the human: Affective entanglements and subjectivity in Hélène Cixous's Algerian reveries
}

\author{
Birgit Mara Kaiser University of Utrecht
}

\begin{abstract}
This article examines the place of the human in Hélène Cixous's work. Taking her extended conversation with Mireille Calle-Gruber ('Entre Tiens') as a starting point, the article shows how Cixous employs the word 'human' to denominate a transformational, embodied process, directed at an ethico-political becoming, rather than to invoke a differentia specifica vis-à-vis other forms of life. She thereby moves our conceptions of the 'human' beyond rational subjectivity and universal humanism, and we find a double investment in the term: Cixous's 'human' takes into account our material existences and affective entanglements with other (human and non-human) beings, but it also invokes our specific capacity as human beings to transform and create ourselves and our environments in unforeseen ways. Such a conception of the 'human' is deeply embedded in Cixous's formative experiences in colonial Algeria, as this article argues with particular attention to Les Rêveries de la femme sauvage (2000) and her writings on Algeria published in Stigmata. Escaping Texts (1998). The article takes two recurring images in these texts as central examples to unravel the links between Cixous's two strands to her understanding of 'human' and her experiences of colonial injustice. After first laying out the two strands, which become explicit in 'Entre Tiens', the article subsequently turns to the figure of Fips, the dog of the Cixous family in Algiers, and to the image of closed gates as markers of colonial dehumanization and racialized social inclusion/exclusion. By thinking through these figures, Cixous analyses the dehumanizing logic of colonialism and antiSemitism and develops her own response to it, arguing for human relationality and affective corporeality, for the human as a specific disposition and responsibility within a larger universe, and she is shown to thus challenge the false humanism of the colonial project.
\end{abstract}

\section{Résumé}

Cet article considère la place de l'humain dans l'œuvre de Hélène Cixous. En prenant comme point de départ sa conversation prolongée avec Mireille Calle-Gruber ('Entre Tiens'), il montre que Cixous utilise le mot 'humain' pour dénommer un processus transformatif, corporel et orienté vers un devenir éthiquo-politique, plutôt que pour désigner la differentia specifica vis-à-vis d'autres formes de vie. Elle déplace donc nos conceptions de l'humain' au-delà de la subjectivité rationnelle et de l'humanisme universel et on aperçoit une conceptualisation double du terme chez

\section{Keywords}

affective corporeality Cixous

human/non-human entanglement subjectivity becoming 
Cixous. Selon elle, 'humain' tient compte de nos existences matérielles et de nos liens affectifs avec les autres qu'ils soient humains ou non. Il évoque en outre notre capacité spécifique, comme êtres humains, à nous créer nous-mêmes et à transformer notre environnement. Une telle conception de l'humain est profondément informée par l'expérience de l'Algérie colonisée. C'est à partir d'images récurrentes dans Les Rêveries de la femme sauvage ainsi que dans les textes sur l'Algérie inclus dans Stigmata. Escaping Texts, que cet article montre le lien essentiel chez Cixous, entre l'expérience de l'injustice coloniale et la conception de l'humain.

L'article se penche d'abord sur ces deux conceptions de l'humain dans 'Entre Tiens', puis il s'arrête à la figure de Fips, le chien de la famille Cixous à Alger, pour ensuite se tourner vers l'image des portes fermées. Ces portes sont le signe de la déshumanisation coloniale et représentent les limites imposées à une société basée sur la ségrégation raciale. L'article montre que par ces images du chien et des portes, Cixous examine la logique déshumanisante du colonialisme et de l'antisémitisme et y réplique par une logique propre, prenant parti pour la relation humaine, pour une affectivité corporelle, pour l'humain comme disposition et comme responsabilité dans un univers étendu. Elle conteste donc le prétendu humanisme du projet colonial.

A mon avis l'Homme n'existe pas en réalité.

(Cixous 1986: 55)

Il faut absolument ne pas lâcher le mot 'humain'. Il est si important.

(Cixous and Calle-Gruber 1994: 40)

In her long conversation with Mireille Calle-Gruber published as 'Entre Tiens' in Photos de Racines (1994), Hélène Cixous is asked about the relevance of the 'human' in her work. She confirms that the term appears frequently in it, but explains that she gives it a very specific twist, trying to wrest it from its associations with both rational subjectivity and universal humanism. Cixous notes that she uses the word 'human' because '[j]e ne vois pas d'autre mot pour parler de cette direction, de ce développement, de ce progrès, de cette croissance, qui se fait ou ne se fait pas, au cours de la durée de notre vie' (Cixous and Calle-Gruber 1994: 39). Rather than invoking a differentia specifica vis-à-vis other forms of life and even before asserting a belonging to universal humanity, for Cixous 'human' denotes a transformational, embodied and directional process, directed at becoming 'more' or 'better' human (cf. Cixous and Calle-Gruber 1994: 41) and thus designates a project or a quest rather than a species. In the same passage of 'Entre Tiens', she immediately insists that becoming 'more human' does not mean becoming a nicer person or philanthropic, but that the development this evokes has to do with becoming 'plus fidèles à ce dont nous sommes faits et à ce que nous pouvons créer' (Cixous and CalleGruber 1994: 39). In the passage, she explicitly links these developments to the question of the sense of our human lives.

Oui, le mot humain revient très souvent chez moi. [...] Après tout, que faisons-nous? Nous vivons mais nous vivons pourquoi? Je pense: pour devenir plus humains: plus capable de lire le monde, plus capables de le jouer de toutes les manières. Cela ne veut pas dire plus gentils ni plus humanistes. 
Je dirais: plus fidèles à ce dont nous sommes faits et à ce que nous pouvons créer.

(Cixous and Calle-Gruber 1994: 39)

Cixous points thus to a double investment in the term 'human'. On the one hand, it indicates human beings as corporeal beings and insists on their material existences - à ce dont nous sommes faits. On the other hand, however, the term human evokes a growth or development directed at becoming more aware of our capacity to create, that is to make and to transform, not only ourselves, but also the world - à ce que nous pouvons créer. Cixous takes the term 'human' simultaneously in these two directions and thereby forges a conceptual tool that allows us, as I want to propose in this article, to move towards a dynamic understanding of human subjectivity, affirming our material existences and potential for transformation at the same time. Having recourse to the term 'human' and then taking the term in these two directions permits us, as I will show in what follows, to push our conception of human subjectivity beyond a dialectic of self/other in order to understand it as a corporeally and contextually embedded existence that is permanently in the making and constitutively entangled with a multiplicity of others. ${ }^{1}$

As we will see, Cixous arrives at her take on the 'human' in close relation to her own experiences of colonialism and anti-Semitism in colonial Algeria. In texts such as 'Stigmates', 'Mon Algériance', ${ }^{2}$ Les Rêveries de la femme sauvage (2000), but also somewhat more cryptically in the early novel Dedans ([1969] 1986), Cixous traces her own 'growth' in relation to a set of central scenes from her Algerian childhood, the growth of both her thinking and her affective and ethical dispositions. Her thinking of the 'human' emerges from her own corporeal exposition to what she calls 'la complication historique et perverse' (Cixous 2000: 122) of anti-Semitism and colonial racism in colonial Algeria. It takes up the set of questions that postcolonial considerations of the production of subjectivity have also explored: the stakes of articulation and of voicing difference vis-à-vis the established relations of colonial power and the representations of colonizer and colonized. Yet, while the term 'subject' is still heavily imbued with precisely such a Hegelian dialectic of self/other, fruitfully translated by Albert Memmi onto the field of colonizer and colonized ([1957] 1985), the move towards the 'human' permits Cixous to shift the angle from a self/ other dialectic and its anti-colonial and postcolonial transformations into a different direction: towards exploring how complex networks beyond binary differences contribute to the production of 'who we are', networks that are themselves part of wider globalized, postcolonial or neo-colonial power structures. The term 'human', as Cixous uses it, thus departs from the dialectical differences along which the 'subject' is still largely imagined and situates human beings as corporeally embedded existences alongside and in exchange with a multiplicity of human and non-human others.

Under these premises, for Cixous the term 'human' serves as a marker of a mortal existence that partakes in a larger universe. This dimension of the term takes concrete form in her work in the figure of Fips, the dog of the Cixous family in Algiers - especially in the texts that return to her Algerian childhood scenes, to which I will turn in detail in section 2 of this
1. I use the term 'entangled' here in the sense Barad has given it in Meeting the Universe Halfway (2007): as an affirmation of the co-dependent and differential production of matter and meaning as 'entangled'. Barad discusses from that angle also the interaction - or intraaction, as she insists in order to highlight the differential constitution of entities in the course of their encounters between human and non-human agents. In this respect, it is also noteworthy that Barad stresses that the possibility of such entanglements does not eliminate asymmetries or resolve responsibilities, something that is also important to Cixous's employment of the term 'human', as I argue here. Barad notes:

Learning how to intra-act responsibly within and as part of the world means understanding that we are not the only active beings - though this is never justification for deflecting that responsibility onto other entities. The acknowledgement of "nonhuman agency" does not lessen human accountability; on the contrary, it means that accountability requires that much more attentiveness to existing power asymmetries.

(2007: 218-19) 
2. 'Stigmates' was first published in English as 'Stigmata, or Job the dog' in Philosophy Today, 1997, Spring, pp. 12-17 and was reprinted in Stigmata. Escaping Texts. 'Mon Algériance' was first published in French in Les Inrockuptibles (20 August-2 September 1997), 115, pp. 71-74 and was translated as 'My Algeriance, in other words: To depart not to arrive from Algeria' in Tri Quartlerly (1997), 100, pp. 259-79 and reprinted in Stigmata: Escaping Texts. Since the French version of 'Mon Algériance' has been impossible to access, quotations are taken in both cases from the texts' English translations by Eric Prenowitz, included in Stigmata. Escaping Texts. article. Through this figure, Cixous explores the relationality of human and non-human life and the implications of this relation for human subjectivity. At the same time, however, 'human' also permits her to designate a specific disposition within such a larger universe: the growth and learning of which human beings are capable and of which we heard Cixous speak earlier. Such growth or development is not to be understood as a marker of human superiority or exceptionalism, as we will see when turning to the figure of Cixous's dog, but as an indicator of a specific responsibility or task of humans as human beings. In the singular case of her own autobiographical trajectory (her own 'growth'), which Cixous performs in her autobiographically informed texts, there are several scenes of exclusion and experiences of colonial violence that left profound traces on her, and to which her work and thinking endeavours to respond. One of the most prominent traces is the image of closed gates, epitomizing the logic of colonial exclusion and segregation. Learning to respond to such experiences, and to do so in ways that do not erect new boundaries, is the second axis of her use of the term 'human'. In a third part of this article, I will therefore consider this task of reading and responding by looking at the concrete image of 'gates' in Cixous's autobiographical texts, and it will become evident that the images of 'Fips' and 'gates' are closely connected. They show how Cixous's affirmation of fluidity and intra-active entanglements, on the one hand, and the crystallization of one's singular being on these grounds, on the other, as two vectors of human subjectivity, are precisely responses to colonial power and dehumanization.

In order to pursue the layers Cixous gives to the term 'human', I will begin my argument by laying out in a bit more detail the two directions into which she takes the term, especially the relevance of affectivity as their required basis. We can then explore how the doubling of the term is engendered from an experience of colonialism and anti-Semitism in colonial Algeria. As we shall see, the stakes of such an idea of the 'human' as embedded growth are ultimately, as Cixous notes in the conversation with CalleGruber, to think the conditions of 'gagner de la terre, fabriquer un sol' (Cixous and Calle-Gruber 1994: 105), of being able to produce a habitat for oneself that permits to 'arriver à habiter dans sa maison' (Cixous and CalleGruber 1994: 44). With such a move, Cixous does not counter colonial exclusion with a more inclusive category of 'humanity', as traditional humanism attempted, nor with sketches of newly defined national or cultural identities, as the identity politics of the recent past have practised. She rather has recourse to the 'human' in order to articulate the responsibility specific to humans to fabricate their own ground, but to do so always on the basis of it echoing a whole - on the basis of an awareness of and openness to difference while affirming the continuous effort of becoming plus fidèles à ce dont nous sommes faits et à ce que nous pouvons créer.

\section{Nous sommes d'abord des êtres sentants, or, on affectivity and being human}

In 'Entre Tiens', Cixous notes: 'Nous sommes d'abord des êtres sentants. Le plus passionné, le plus passionnant en nous, c'est la quantité, le déferlement d'affects extrêmement fins et subtils qui prennent notre corps comme lieu de manifestation' (Cixous and Calle-Gruber 1994: 27, emphasis added). 
And a little later in the conversation, she confirms that for her this implies the common ground of human beings: 'Ce qui intéresse tous les êtres humains, c'est ce qu'on appelle les affects, ce qui nous préoccupe: c'est le pré- de l'occupation, ou le post- de l'occupation' (Cixous and Calle-Gruber 1994: 77). The material and affective dimensions of human life are in fact Cixous's starting point for any quest to become 'more human': the fact that we are perceptive and sentient beings, that we are made from and continue to be dust, a materiality shared not only with other human beings but also with other organic and non-organic life (and which we usually scorn, as Cixous notes (cf. Cixous and Calle-Gruber 1994: 41-42)). It is first of all this basic constitution of which the term 'human' reminds us. The fact that 'human' means (d'abord, as she says) a corporeal existence partaking in a material whole implies, however, that we can also exceed the immediate boundaries of our own limited being to a certain extent.

Être mieux humain, c'est aussi cela: ne pas être enfermé dans sa petite durée, dans sa petite maison, dans sa petite voiture, dans son petit sexe, mais savoir qu'on est une partie d'un ensemble qui vaut 'le déplacement' - de toutes nos pensées.

(Cixous and Calle-Gruber 1994: 42)

Because we are co-constituted by affective resonances with and effects of others, we are not fully enclosed within the narrow time span of our lives (durée), our limited territories (maison), the boundaries imposed by class (voiture), sex and also implicitly species, something Cixous does not address explicitly in the above passage, but which underlies many of her texts, as we will see when we turn to the figure of Fips. She renders this ability to transgress our own narrow bodies and minds as an echo of other beings and the universe: '[M]ieux humain. Cela signifie, en effet, tout en étant humain ne pas se priver du reste de l'univers. C'est pouvoir se mettre en écho - travail complexe mais magnifique - avec ce qui constitue l'univers' (Cixous and Calle-Gruber 1994: 41). On the basis of her insistence upon humans as corporeal existences, the echo of which she speaks here is not the reflection of a universal principle within different beings, nor simply the reflections within us of a prearranged and established universe. It also does not primarily refer to our participation in a universal humanity, but rather denotes a corporeal labour, a becoming faithful to and capable of - '[la] sensation de faire corps avec tout le temps, toute la substance vivante du temps' (Cixous and Calle-Gruber 1994: 43). Starting from a perspective where the corporeal-affective constitution of human beings makes the term 'human' a designator for resonating beyond the boundaries of a culture, a nation or even a species - of affecting and being affected by a multiplicity of others, events, circumstances, encounters, elements, vibes, etc. - Cixous then makes a significant second turn and uses the term 'human' also to evoke the specific task of humans. The constitutive and continuous openness to and resonances with multiple others calls for the very task to fabricate a 'ground' in the sense of humans moulding and creating the specific articulations of their singular desires and histories: '[N]ous ne sommes pas sans un environnement, humain 
3. For écriture féminine, cf. Cixous ([1975] 2010a). There Cixous notes that writing is not a question of representation and that the practice itself is not representable by means of a definition. It is '[i] mpossible de définir une pratique féminine de l'écriture, d'une impossibilité qui se maintiendra car on ne pourra jamais théoriser cetter pratique, l'enfermer, la coder' (Cixous [1975] 2010a: 50). But as a practice, it sets out to undo the phallocentric representations of desire, subjectivity and sexual difference, and manifests itself as 'l'invention d'une écriture neuve, insurgée qui [...] lui [la femme] permettra d'effectuer les ruptures et les transformations indispensables dans son histoire' (Cixous [1975] 2010a: 45). For the link of feminine writing to the writing and rewritten body, cf. Ian Blyth and Susan Sellers (2004: 18-34), as well as the interviews collected in Cixous (2008a: 51-94). While Verena Andermatt Conley suggests that the encounter with Lispector produced a move in Cixous's work 'from feminine to human' (as the title of Chapter 5 of Andermatt Conley's Hélène Cixous (1992) notes) and sees from then on Cixous's greater attention to 'cultural pluralism' and view of 'the woman's question [...as] one issue among many' (Andermatt personnalisé, personnel; et terrestre, urbain, etc. ("politique" - cela vient pour moi après coup)' (Cixous and Calle-Gruber 1994: 41). Within the circumstances and conditions in which we find ourselves, we have to grow and to transform these very circumstances and conditions in the course of that growth. Given the fact that we are embedded in them, we are called upon, as we saw above, to also 'play' them in different ways - plus capable de lire le monde, plus capables de le jouer de toutes les manières - whereby 'play' suggests a certain freedom or leeway, variations of tune, performativity and the potential to (re)articulate the world in new ways.

In this light, for Cixous, 'human' also describes a disposition specific to human beings, as beings endowed with language and reflection. She famously explored a strong belief in the powers of language in 'Le Rire de la Méduse' ([1975] 2010a) and 'Sorties' ([1975] 2010b). Our capacity to create and transform our ways of seeing things, and expressing the world in ways we deem more desirable, manifested in a creative inflection of language, was already at the basis of Cixous's notion of écriture féminine. ${ }^{3}$ But beyond the feminist implications of modulating language in ways that allow women to explore and (corporeally and linguistically) articulate their desires and to create feminine modes of existence, it is relevant to note in the present context that Cixous employs the same potential for the 'human' beyond sexual difference. In 'Entre Tiens', she remarks:

Quand je parle de l'humain c'est peut-être aussi ma façon d'être toujours traversée par le mystère des différences sexuelles. Par cette espèce de double écoute qui est la mienne. J'essaie tout le temps de percevoir, de recevoir, des excitations, des vibrations, des signes venant de lieux sexualisés, marqués, différents; et puis, en un certain lieu - un point à peine, ou bien un pointvirgule - la différence laisse place à (mais c'est plutôt que les deux grand courant se mêlent, se jettent l'un dans l'autre, pour n'être que) ce qui nous attend tous: l'humain [...].

(Cixous and Calle-Gruber 1994: 40)

What Cixous highlights here is a sort of 'double listening': paying attention, on the one hand, to the specific (the marked, the sexed, the dated) and, on the other hand, to that which exceeds the specific and is shared and common. We find the same dynamic at the heart of her use of the term 'human'. On the one hand, she stresses corporeal existence as shared with (human and non-human) others, and in this sense 'human' is that which exceeds the specific, a denominator for what is shared and common across differences of culture, sex or even species. On the other hand, Cixous makes 'human' the name for a transformational practice and the specifically human task of reading and recreating the world, and 'human' becomes the name for a specific ethico-political becoming. Such a becoming indicates an awareness of a shared stratum of existence on which the divisions of species, classes or sexes are not (yet) in effect, and works at the same time towards sensibly and carefully reading the world in order to modulate it, intervene in and rephrase it, thus assuming our human responsibilities. It is in this light that one can perceive two vectors to Cixous understanding of the 'human', as I argue: one towards the dissolution of boundaries, stressing 'human' as a reminder that we relate to 
others on a fundamental level so that any 'I' echoes a larger whole (a whole she takes as wide as the universe); the other towards the powers of becoming in such ways as to manage to 'live in one's house', designating a situated and open-ended growth during our lives, based on scrutiny and reading in a broad sense. ${ }^{4}$ It is true that by doubling the term in this way Cixous forestalls any conclusive definition of it, as she herself acknowledges:

[C]'est qu'on ne peut pas définir, finir, fermer, clore la définition humaine pas plus que la définition sexuelle. De tous côtés il y a des points de fuite, des points de communication, des points de plus et de moins. C'est nous, avec notre langage, qui faisons clôture.

(Cixous and Calle-Gruber 1994: 60)

The fact that for Cixous 'human' extends into these two directions at the same time - a movement of opening up and entangling beyond the individual bodies and beyond the human species on the one hand, a progress of specification and fabricating a ground on the other - might only seem contradictory if we ignore the basis on which both rest. That is, affectivity as a trait shared by all humans, thus exceeding their particularities, and a trait shared by humans and non-humans, thus deconstructing the anthropocentric delimitation of human and animal. ${ }^{5}$ Cixous's thinking of the 'human' in this sense clearly takes its distance from classical humanism and the latter's stress on rationality as a common human - and exclusively human - ground. While traditional humanism took rationality not only as the presupposed common ground of humanity but also as a line of demarcation of the human from the non-human, affectivity, in contrast, is a marker of both a corporeal potential shared by all humans and a quality shared by humans and non-humans alike, albeit to different degrees and with different implications. It is precisely on this basis that Cixous can speak of 'human' as a potential to echo the universe, to exceed not only the particularities of different communities, of cultural and sexual differences, but to also partake in and respond to pulsations that touch human and non-human life alike. When Cixous claims that '[c]e que nous sommes capables de faire comme exercice de traduction avec le corps ou comme traduction de nos affects en termes de corps est illimité' (Cixous and CalleGruber 1994: 38), there is no reason to presume that such translation is limited to affects that resonate with or originate in other human beings. In immediate relation to her writing practice, Cixous describes these resonances as 'further-than-myself' in many respects: 'J'écris aussi afin d'aller plus loin, plus loin que ce que je dis, et ça n'est pas impossible. Je peux aller plus loin que moi parce qu'il y a du plus loin que moi en moi - dans tout être' (Cixous and Calle-Gruber 1994: 65, emphasis added). Such a further-than-myself is possible because 'I' is no self-identical, indivisible atomistic unit, but because any 'I' is always constituted by difference, in corporeal relations with others and within a continuously transforming environment - very much in the fashion of a philosophy of difference and its consideration of otherness, to which Cixous is indebted. Accordingly, she explains in 'Entre Tiens' that '[m]oi ce n'est pas moi, bien sûr, puisque c'est moi avec les autres, venant d'autres, me mettant à la place de l'autre, me mettant les yeux de l'autre' (Cixous and Calle-Gruber 1994: 96). And
Conley 1992: 82),

I do not see these

two perspectives as successive. Instead of a shift from a too narrow interest in femininity to a more inclusive category of 'human' and cultural difference, I rather see these two as allowing Cixous to pose different questions. The feminine is the name for sexually marked difference, and thus enables the exploration of differences, while the human permits the exploration of a dynamic understanding of subjectivity.

4. I employ the term 'becoming' here as an ethical project in the sense Kathrin Thiele proposed, with recourse to Gilles Deleuze, in The Thought of Becoming: Gilles Deleuze's Poetics of Life (2008). The resonances between Deleuze and Cixous, especially between their emphasis on life and its challenges to our traditional humanist notions of the human, are manifold and warrant an investigation in its own right. For Deleuze's appreciation of Cixous's practice of writing as one that has affinities to his own concept of literature cf. Deleuze (2004).

5. For a discussion of affectivity as a corporeal disposition, cf. B. Kaiser (2011). 
6. It was the fact, as she notes in 'My Algeriance', that 'a living fragment of my maternal family had landed [in Algeria] after it blew up on the Nazi minefield' (Cixous 1998a:

204) that lead to the complications of her situatedness in Algeria and her exposure to exclusion and colonial violence.

She even notes that her "way of thinking was born with the thought that I could have been born elsewhere, in one of the twenty countries' (Cixous 1998a: 204) where other members of the family had emigrated to, stressing chance and contingency, as well as the difference that situatedness within particular locales make.

7. On Cixous's animals and her animots $\mathrm{cf}$. Goh (2010) and M. Segarra (2006). again, we have no reason to deduce that for Cixous these others are human others only, a fact of which the story of Fips, to which I will turn momentarily, gives evidence. For Cixous, a further-than-myself - a surpassing of our own limited bodies and environments, which forms the very basis of the movement of opening up and co-responding beyond the individual and beyond the human species, which I have called the first vector along which Cixous takes the term 'human' - is conceivable 'in all beings', dans tout être. A little further on in the conversation with Calle-Gruber, Cixous herself raises the question of who these others are: 'Ce plus loin que moi en moi ne peut être qu'un mélange d'autres et de moi. Des traces d'autres, les voix de mes autres - mais qui? Nous sommes pleins de voix, comme toutes les îles' (Cixous and Calle-Gruber 1994: 65). At this point, she names her 'imaginary' Talmudist great-grandfathers as an example of such traces, dead others whom she never knew and imagines with the help of photographs and the stories her mother tells her about them. These imaginary others permit her to exceed her own durée in a certain sense, to see the traces left in her own life by her mother's German Jewish ancestors. ${ }^{6}$

However, in addition to these human ancestors, we also have to take into account the many non-human beings that populate Cixous's textual planet, from Kleist's marionettes to the puppets of Tambours sur la Digue, from the donkey of 'Ecrire aveugle' to the cat in 'Aube partagée' or the ants mentioned at various instances, and most relevant for this context the prominent narrative of Fips, the dog of the Cixous family in Algiers, which surfaces at crucial moments in Cixous's writings. When looking in detail at the figure of Fips, it becomes clear that the further-than-myself extends even beyond imaginary or dead human others and that Cixous radically situates the 'human' within a multifaceted network of human and non-human others, within a universe and within circumstances that are echoes of a further-than-myself in any 'I with the others', something that we fabricate and which we usually call 'identity'.

\section{Mon petit frère fauve enfiévré; or, on Fips and other animots}

From among the many animals ${ }^{7}$ that appear in Cixous's work, I would like to focus now on the narrative of Fips as a case in point, since the responses to Cixous's Algerian scenes are of particular relevance to my argument. To begin with, we can see how the figure of Fips allows Cixous to sketch concretely what I have so far presented more theoretically as her affirmation of the 'human' as an existence within a shared universe. Fips appears prominently in Cixous's autobiographically informed later texts, especially in 'Stigmata, or Job the dog' and Les Rêveries de la femme sauvage, but is also already encrypted in the figure of the dog that appears in the early novel Dedans. If we take Fips - as Cixous herself suggests in her later work - as a crucial wound she received at young age, his trajectory in her work, from the early novel to the later autobiographical sketches, signals not only a deconstruction of the human/animal divide, but indicates and performs also her own work of learning and growth in regard to this particular experience. The early Dedans begins with a child's recollection of her father's untimely death and the eerie simultaneity of his haunting presence and painful absence in the child's life, something to which Cixous 
returns frequently in many of her texts. In Dedans, one of the games the narrator and her brother invent in order to escape the anxiety and pain their father's death inflicts is to play dog:

EXERCISE. Mon frère ou moi ou le chien qu'importe, l'un de nous est un chien, nous sommes un chien chacun à son tour. [...] Exercice: 'Regarde, je vais courir jusqu'à ce que ta peur et ma peur s'épuisent à me suivre.' Chien, je cours, je les dépiste, je prends de la vitesse, elles perdent du poids, je souffle, elles tournoient [...].

(Cixous 1986: 39)

Dedans does not make explicit that the dog alludes to an autobiographical scene that is saturated with life in Algeria in the late 1940s. Here, it might thus seem mere child's play, the dog as an imaginary, casual figure. But later in 'Stigmata' and in Revveries, we realize the seriousness of this triangle of 'mon frère ou moi ou le chien'. Both texts revisit the life of the Cixous family in colonial Algeria. The narrator of Reveries recalls that, having moved, in 1946, from Oran to the Algiers neighbourhood Clos-Salambier, at the time a so-called 'Arab'8 neighbourhood, the father gave the narrator and her brother a dog. It was an overdetermined event, as the children had waited long and in vain for another sibling and welcomed the dog as their 'troisième enfant, [...] un bébé, un enfant de notre père mourant' (Cixous 2000: 74). However, timing was bad: the dog came too late to be cared for by their father, who looked after him until his premature and sudden death, and it came too early for the children to take on that task. In 'Stigmata', Cixous acknowledges that 'we the children were not ready, we were far from having the animal height and even from imagining that it existed' (1998c: 250), something that Dedans had still playfully ignored by intonating the child's perspective. In Reveries, the narrator remembers that they had wished for a being they could put in a shoe box cradle fitted with 'feuilles sèches de bougainvillées, duvet de poules' (Cixous 2000: 74), but he would not stay put and instead roamed the neighbourhood. With the father's death and the respect paid to him as a doctor no longer granted, the children's position in the neighbourhood changed and the narrator experienced the Clos-Salambier as an increasingly hostile environment. She felt rejected as one of the 'Cixous children those not really Jewish false French odd inadequate people who loved the Algerians who spurned us as enemy Francaouis, Roumis and Jews' (1998c: 215), as she notes in 'My Algeriance', a 'qualification' of the 'Cixous children' that sums up in a nutshell a whole web of colonial violence and of mutual projection and rejection in colonial Algeria. And in Reveries, the most extensive of this dense network of autobiographical texts, the narrator describes life as increasingly withdrawing behind the gates of their house.

We find a similar impression and an exaggerated image of internment already in the early novel Dedans, which starts as follows: 'MA MAISON EST ENCERCLEÉ. ELLE EST ENTOURNÉE PAR LE GRILLAGE. DEDANS, nous vivons. Dehors ils sont cinquante mille, ils nous encerclent' (Cixous 1986: 11). After this opening, the child, from whose perspective the narrative is told, then imagines fleeing from feelings of containment and anguish by assuming a dog's speed - '[j]e cours, je cours, je cours, je cours vite, si
8. In 'Stigmata, or Job the dog', Cixous notes that ' $[\mathrm{t}]$ he word Arab belonged to French colonization' (1998c: 246), applying a generalized label to the native population and disregarding ethnic, linguistic and religious differences; just as talk of 'French' neighbourhoods is 'also colonial vocabulary' (1998c: 246). It is with this reserve in mind that the terms are used here. 
9. Next to the capitalized Dog, the equally capitalized Bike features in Les Rêveries de la femme sauvage as another 'primal scene' of their Clos-Salambier childhood. While the Dog is a marker of racialized difference and a reminder of the dead father, the Bike manifests sexual difference, of a brother opting for going out and a sister opting for turning towards reading instead (cf. Cixous 2000: 19-27).

10. Fips is, thus, both this singular family dog, a concrete event that took place in reality and left marks on a singular body and a 'signifying network' involving too many players and stakes to unravel fully, from the father's choice of living in the Clos-Salambier, the siblings' disappointment with the aliveness of the animal, the father's untimely death, to 'Omi-avec-maman' (Cixous 2000: 79) not recommending feelings for animals, the difference between brother and sister to go for the Bike and books, respectively, as responses to living where they lived, to ultimately even the dog's heir, the cat. bien, mes quatre pattes brûlantes, dures, parcourues d'un liquide en effervescence [...] si vite que je n'entends plus les bruits des poules et des gens' (Cixous 1986: 40) - and brother, sister and dog become indistinguishable partners in crime. When Cixous returns to the relation of brother, sister and dog in the later autobiographical reveries, a different reading of those scenes is presented: the dog has now become part of a painful memory of three jointly distressed beings. Increasingly kept inside the garden and delivered more and more to a chained fate, Fips becomes a marker of the narrator's own feeling of exclusion from an 'Arab' neighbourhood that sees her - through a grid of colonially established, racialized segregation - as 'French'. The triplet that in Dedans had still evoked child's play in 'Stigmata' has become a trio joined in pain: '[T]hey threw stones at us and we were three severely wounded beings who ran bristling in the garden transformed by the assault into [sic] obligatory box' (Cixous 1998c: 255). However, while the brother opts for using their Bike ${ }^{9}$ to cycle through the city with the other boys, as Reveries unravels at length, the narrator withdraws to reading and stays inside, with a feeling of confinement she likens to that of the dog: 'Et Le Chien comme moi, ni pain, ni paix, ni espérance. La haine el l'absurdité. Nous étions tous des chiens enragés les uns contre les autres [...]' (Cixous 2000: 78). The figure of Fips is to a certain extent a symptom of this strong sense of exclusion that pervades Dedans, 'Stigmata' and Rêveries. And in retrospect, the narrator of Revveries notes that Fips was an epitome of her Algeria: '[C]'est le destin du Chien selon moi qui est la métaphore et le cœur de toute l'histoire, la transfigure de la famille et le résumé de nos Algéries mais pour mon frère c'est Le Vélo' (Cixous 2000: 72). The dog comes to signal 'un ensemble signifiant' (Cixous and Calle-Gruber 1994: 39) - an entire 'signifying network' of scenes, affects, events, stories, a nodal point that permits Cixous to trace some of the effects of the colonial experience, as it was brought to the point by her relation to this dog. ${ }^{10}$

However, the fact that Fips features - as the subtitle of Reveries indicates - as one of the 'primal scenes' of this childhood makes him more than a 'mere' metaphor of Algeria. When Cixous writes in 'Stigmata' that she has 'that dog in my skull, like an unrecognizable twin' (Cixous 1998c: 249), the whole scene of Fips becomes one of Cixous's decisive 'psychomythical event[s]' (Cixous 1998c: 245), one of the stigmata that give the text its title: concrete wounds that leave momentous traces of painful yet passionate encounters and mutual suffering, corporeally real and haunting at the same time. The traces of Fips are particularly complex as they are not only a memory of being wounded alongside each other, as we heard above, but also of being wounded by each other - traces of internal strife, disappointment and betrayal. After the father's death, the family increasingly neglected the dog, partly due to the fact that it was understood in the maternal generations that to have feelings for an animal "is not recommended"' (Cixous 1998c: 254), partly due to Fips reminding the narrator of her father's absence. All of this climaxed in a significant misunderstanding, when one night, as the narrator of Reveries recalls, Fips mistakes her for one of his tormentors and bites her foot:

Je lisais. On sonne. Je lis. On sonne au portail enchaîné et cadenassé. [...] Somnambule je surgis de mon livre, furieuse, et j'abats mon pied sur le sol 
devant la cuisine. Ici jaillit la nuit du malentendu. Ici jaillit Le Chien. [...] Il lui sembla que j'attaquais. Il lui parut monstrueux que maintenant moi je l'attaque. Il n'y a pas de crime et de trahison à laquelle sa propre famille reste étrangère pense-t-il. Et dans un grand frisson rauque il se jette sur le pied que je lève vers lui. [...] Nous étions devenues inséparables.

(Cixous 2000: 79-80)

Where the two had been imaginary partners in crime in Dedans, and in Rêveries until this point jointly submitted to the distant and distorted effects of colonial discrimination, it is now - as a result of a misunderstanding and unfavourable circumstances - that they turn against each other. From the child's perspective, the narrator recalls the abandonment as mutual: 'j’ai connu avec lui la forme la plus basse de la vie familiale: le ressentiment sous le même toit, un silence empoisonné' (Cixous 2000: 80). However, written 40 years later as a revisiting of these Algerian scenes, the narrators of both Reveries and 'Stigmata' realize that what the child saw as two hurt creatures almost on a par was also the abandonment of a suffering companion and the child's incapacity, under these circumstances, for compassion. Although unacknowledged at the time, in retrospect the narrators of both texts see the dog's suffering as resonating with her own and note that 'I was the non-keeper of my dog' (Cixous 1998c: 259) and that she abandoned 'mon petit frère fauve enfiévré' (Cixous 2000: 77) to an army of tics, stones and worsening infections. In hindsight, she sees that as a result of their intense physical and emotional entanglement, the figure of Fips marked her for life: 'J'ai son âme sous le crâne, j'ai ses dents et sa rage peintes sur mes pieds et mes mains, j'ai Le Chien, tout Le Chien, depuis les origines jusqu'au suites, gravé dans la membrane de ma mémoire' (Cixous 2000: 73). Rewriting the scene from Dedans to Reveries marks and performs a process of learning, a growth that retains the physical encounter, yet strives to become 'better human' as an effect of it and in response to it. Acknowledging that she failed her 'little fever-struck brother' at the time and revisiting the scene and the scars it left is performed here as the task to account for ourselves and grow from this, an accountability that requires also, as Karen Barad noted especially for human and non-human intra-actions, 'much more attentiveness to existing power asymmetries' (2007: 219).

In view of this, the figure of this dog - and of the whole network of relations and significations that come with it - indicates, as I argue here, a specific condition to which Cixous points us. From among the many animals that populate Cixous's writings (cf. Goh 2010), what is particularly relevant to the figure of Fips is that the affectivity and corporeality, the relationality and affirmation of difference involved in this story - all of which permits to think the subject as further-than-myself (rather than a closed off indivisible unit) and as 'I with the others' - is not limited to human others alone. The traces of others - '[d] es traces d'autres, les voix de mes autres' (Cixous and Calle-Gruber 1994: 65, emphasis added) which compose any further-than-myself in myself are also those of my non-human others. As Goh has shown, the different avatars of animals the donkey in 'Ecrire aveugle' or the ant to whose perspective Cixous likens her writing practice in 'Entre Tiens' - enable Cixous to approximate 
11. For a reading of Cixous's deconstruction of an anthropocentric understanding of the human/animal relation, cf. also Segarra (2006). an angle from which to view the world differently than from what we usually call human vision. These animal figures, Goh suggests, are manoeuvres to move away from a vision that orders and classifies, names and hierarchizes, a vision that she calls at some point "une station debout, analogue à celle de qui s'affirme théoricienne' (Cixous and Calle-Gruber 1994: 17). Such a manoeuvre aims at approaching that which is in movement and not yet divided or hierarchized. Goh rightly notes that by means of these figures Cixous attempts to 'abandon the human condition and follow the animal, or [to] pass into an animal point of view' in order to 'write the passage of the instant without stopping to learn or conceptualize' (Goh 2010: 1059). In 'Ecrire aveugle', she likens herself to the donkey in order to permit perspectives and pulsations that escape human vision, if we mean by human vision a mode of perception that produces knowledge that grasps the world, seizes, arrests and orders it. Accordingly, she notes in 'Entre Tiens' that she always sees herself 'comme cette fourmi, cette petite lettre qui se promène dans un livre dont on ne voit pas la fin' (Cixous and Calle-Gruber 1994: 43). And surely the ants and the donkey facilitate a certain way of seeing beyond a cognizant post-lapsarian human vision, as Goh discusses it. However, as we have seen from the stress on their joint suffering but also their intense infliction of pain upon each other, Fips is an indicator of something more specific. The narrator does not pretend to present Fips' side of the story, or slip into his view of things, but tells the story of the marks left by their significant encounter. The figure of Fips sketches being deeply touched and hurt by the animal other, as well as deeply hurting this other in turn, rather than - as the ants do - permit 'smuggling oneself into an animal point of view or condition' (Goh 2010: 1060. Emphasis in original). In 'Stigmata, or Job the Dog', Fips is said to be

the character the most secretly necessary and marking of the flesh of my soul. [...] I am the result of his visit. Indelible are the traces of his cruel stay in my flesh and my soul. It is to him that I owe my scars. He is the innocent author of the signatures that inaugurated my book on my feet and my hands. [...] the marks of the cries are lodged on the sensitive very sensitive membranes of my brain.

(Cixous 1998c: 249)

The story of Fips is presented as the narrator's initiation to a shared affectivity and passion that constitutes and exceeds the human, without denying differences in responsibility or in the chances to process and distil the effects of such encounters. This dog is the emblem of a corporeal existence susceptible to and productive of affects and traces, of an affective-corporeal constitution that composes 'me' always as a network of traces and echoes of others, reliant on a 'further-than-myself in myself', which includes not as mere metaphors or footnotes, but as momentous marks on real feet - human and non-human others. To stress such a relationality renounces the anthropocentric opposition of human and animal and inscribes 'human' quite clearly into a larger whole, without diminishing the differences between human and non-human agency or denying human responsibility. ${ }^{11}$ Revveries and 'Stigmata' precisely hold the narrator accountable - they give an account of this encounter. The forceful marks 
left on the dog by human neglect are lethal and beyond redress. The forceful marks left by the dog's fangs on the narrator's foot remind her of this neglect, but also of what we are made from (ce dont nous sommes faits), literally and metaphorically speaking: both in the sense of our mortal condition, the dust that we are and share with other mortals, and in the sense of the psychomythical traces that constitute us. Cixous learns from these scars and she makes 'human' the term to address this: moving it from defining the boundaries of a species to designating a corporeal existence that (even unwittingly) resonates with the world to different degrees and that summons us, precisely as human beings, to answer to and to read the events and the traces this leaves. We have thus, already in the story of Fips, touched upon the second vector of the term 'human', which Cixous equally develops in relation to her Algerian childhood scenes: the responses and readings we are summoned to give and whereby we are able to fabricate a ground to live on. When turning to the image of 'closed gates' now, the immediate relation of such a response to the experience of colonial dehumanization will become even more apparent.

\section{Les Grilles m'assignent à répondre; or, the Algerian passions of H.C.}

While the figure of Fips plays a central role in Cixous's texts in the respects discussed so far, the revisiting of something as seemingly mundane as the family dog also already performed the second aspect of the quest that Cixous calls 'human'. By re-examining the interwoven 'signifying networks' of the Dog and the Bike, but also of the Clos-Salambier and of closed gates, the narrator practised already what Cixous sees as the term's second axis: to read the world and (re)articulate it. To the complications and entanglements that result from our condition as sentient beings, from our corporeal exposure to others - none of which is exclusively human Cixous adds the task that precisely as human beings and in order to become 'better human' we have to transfigure, that is to read these entanglements and to learn from them. When she notes, in 'Entre Tiens', 'que la souffrance est une noblesse de l'être humain' (Cixous and Calle-Gruber 1994: 30) she does not endorse suffering and pain, nor does she ignore or trivialize victimization and injustice, but she stresses that 'human' means also to aim at deriving a certain growth from the passions or affections that we undergo. Human beings, she suggests, try to live even through the worst suffering, 'essaient de les vivre [les pires souffrances]. D'en faire de l'humanité. De les distiller, d'en comprendre la leçon' (Cixous and CalleGruber 1994: 29). As we began to see in regard to Fips, Cixous draws on her Algerian primal scenes, on these multifaceted 'signifying networks', in order to learn from them. She 'transfigures' them into significant elements of her thinking, such as her understanding of the term 'human'. In 'Sorties' - in a passage that Robert Young already famously pointed to in White Mythologies as marking a certain germinal moment in poststructuralist theory (1990: 1) ${ }^{12}-$ Cixous makes this point as follows:

Avoir vu les 'Français' au 'sommet' de l'aveuglement impérialiste se conduire sur une terre habitée par des humains comme si elle était peuplée de non-êtres, d'esclaves-nés. De ce premier spectacle, j'ai tout appris: j'ai vu
12. For similar arguments as Young's, which pay much more detailed attention to the relation between Algeria and the generation of Cixous's thinking, as well as post-structuralism in general, cf. J. Hiddleston (2010) and P. Ahluwalia (2010). 
comment le monde blanc ('français') supérieur ploutocratique civilisé instituait sa puissance à partir du refoulement de populations soudain devenues 'invisibles' [...]. Invisibles en tant qu'humains. Mais bien sûr perçus en tant qu'instruments, sales, bêtes, paresseux, sournois, etc. grâce à la magie dialectique anéantissante.

(Cixous [1975] 2010b: 84-85, emphasis added)

To have witnessed the dehumanizing effects of colonial power and the denial of humanity to a colonized people had a deep impact on Cixous's thinking, sharpened by the personal and contingent, yet formative 'stigmata' we exemplarily traced by means of the figure of Fips. She repeatedly notes that these scenes from her childhood, including the various materializations of the above-described 'spectacle', engendered her writing and her way of thinking (cf. Cixous 1998b: xvi, xx). What she remarked at a colloquium on Derrida à Alger about the profound influence of such scenes upon her friend's work can also be read as a comment on her own work: 'On est à jamais blessé et révolté par cette scène: voir de nos oreilles hommes et femmes non francophone être mutilés diminués, leur langue rendue vaine devant la langue dominante' (Cixous 2008a: 56). As someone highly susceptible to the pleasures of language, to what she elsewhere calls her 'francolinguistic exstasies' (Cixous 1998a: 225), Cixous is particularly sensitive to the deprivation of it witnessed with her Algerian neighbours. And when in 1940 the French withdrew French citizenship from the Jewish population of Algeria - an experience that J. Derrida discusses in Le Monolinguisme de l'Autre (1996) as crucial for his own relation to the French language and his philosophy of difference - Cixous realized that the Jews of Algeria 'were like the Arabs identical twins in deprivation' (Cixous 1998a: 225). While the narrator of Rêveries can muster compassion for the Dog only in hindsight - or it takes her 40 years to read its lack and the implications and conditions of that lesson - her Algerian scene was imbued already at the time with an intense feeling of solidarity and compassion for her Algerian neighbours, despite feelings of isolation in the Clos-Salambier: 'The anguish of my fellow people pierced me. I was struck, wounded, marked, scarred' (Cixous 1998a: 219). And in the face of colonial violence and humiliation she sees that "mes frères de naissance sont arabes' (Cixous 2010b: 87) and that these experiences made her realize that '[j]e suis du parti des offensés, des colonisés. Je (ne) suis (pas) arabe' (Cixous 2010b: 87).

In 'Letter to Zohra Drif', Cixous discusses these feelings of solidarity and compassion by addressing herself - again in hindsight in a letter she never sent off - to Zohra Drif, one of the three Algerian girls that entered her class at the Lycée Fromentin in Algiers when Cixous was 13. She was excited when they enrolled, as it meant that she was no longer the only one who was different among her 'French Algerian' classmates. Cixous was the only Jewish girl in a school, which had not only eagerly complied with Vichy laws when they were in effect, but continued, as she remembers, 'the pleasure of exclusion' (Cixous 2003: 85) even beyond the war. As she recalls, the school 'smelled of Vichy [...]. I detected the lingering odors of racism and colonialism in the teachers' (Cixous 2003: 85). She therefore welcomed the arrival of her three new classmates as a moment 
of relief, 'in an indefinable way a discovery, a reunion, an alliance, because with them I made sense to myself' (Cixous 2003: 87). Already Rêveries had dwelled briefly on the girls Zohra, Samia and Leila, who the narrator hoped might allow her to break out of her feelings of solitude and estrangement. But she realizes that they remain separated by the divisions and walls that were erected between groups in colonial Algeria. In Rêveries, the narrator recalls the intense alliance that she felt with them:

J'étais attachée à leurs trois présences. J'étais avec elles et elles n'étaient pas avec moi, j'étais avec elles tenue loin d'elles par tous mes fantômes et tous les mots de barbaries [...] j'étais avec elles sans elles avec moi qui à moins d'elles ne pouvais être moi. Je voyais toutes mes algéries face à face.

(Cixous 2000: 151)

As we have seen in the case of Fips, also here the relation to 'Algeria' - a 'signifying network' brought to the point by the three Muslim girls coming to her school - is not reciprocal or shared. In Reveries, the narrator acknowledges that '[j]e vois que Zohra Drif, à côté d'Elle n'est au courant de rien' (Cixous 2000: 154). And in 'Letter to Zohra Drif', she notes this peculiar feeling of alienation and her desire to join the three friends, saying that while she 'loved them [...] they lived in me, I did not inhabit them' (Cixous 2003: 87). The text continues to explain this rift by the bars that enclosed each on their respective sides:

I called to them in silence and without hope. I was behind the bars of a mad destiny, cooped up with the French my non-fellow creatures, my adversaries, my hands held out toward my kind, on the other side, invisible hands held out to my own tribe who could not see me. For them, surely I was what I was not: a French girl. My ancient desire for them, my desire for innocence, for purification, inaudible. There was no us.

(Cixous 2003: 87. Emphasis in original)

What Cixous describes here in her imaginary address to Drif is the peculiar situation that Derrida - also with reference to his own situation as a French-speaking Jew in colonial Algeria - calls '[c]ette structure d'aliénation sans aliénation' (Derrida 1996: 48), a displacement from a place one never had, pierced by a sense of loss of something one never possessed. ${ }^{13}$ Cixous remarks in that regard that she "did not lose Algeria, because I never had it, I never was it. I suffered that it was lost for itself, separated from itself by colonization' (Cixous 1998a: 224). She describes this in different texts as an obscure feeling of 'not belonging to any here by inheritance or descent, the physical feeling of being a frail mushroom, a spore hatched over night' (Cixous 1998a: 205), of being '(not) Arab', as we heard, and at the same time 'a French person without France' (Cixous 1998a: 224), and coins the term mon algériance for this condition, 'cette sensation d'être possédée par une sensation de dépossession' (Cixous 2000: 16). Despite a strong sense of solidarity with the Algerians and a joint exclusion from 'Frenchness', any straightforward 'identification' and bond with the Algerian people or any straightforward belonging or presumed concurrence of national identity, language, citizenship and
13. In Le Monolinguisme de l'autre, as well as in more cryptic fashion in his philosophy at large, Derrida transfigures this experience into a questioning of the very idea of property when it comes to language and identity. He explains the peculiar predicament of his position in the Algeria of his youth in a conversation with Mustapha Chérif as follows:

The community to which I belonged was cut off in three ways: it was cut off first both from the Arab and the Berber, actually the Maghrebin language and culture; it was also cut off from the French, indeed European, language and culture, which were viewed as distant poles, unrelated to its history; and finally, or to begin with, it was cut off from the Jewish memory, from that history and that language that one must assume to be one's own, but which at a given moment no longer were $[\ldots]$.

(2008: 34)

Although

comparable, there are significant differences to Derrida's and Cixous's situation and to their choices in terms of where and how life comes to influence work ( $\mathrm{cf}$. note 17 ). 
14. Cixous intonates these harsh segregations of communities in colonial Algeria when she calls the fact that the Cixous family lived in Algiers in the Clos-Salambier 'a gesture of great freedom on the part of my father' and continues that

one did not live in the Clos-Salambier it was not done, the Europeans the French lived in town $[\ldots]$ one lived in Bab El Oued, in Belcourt, rue Michelet, or in the more reputable neighbourhoods, El Biar or Hydra but beyond the bd Bru, no it was not done there was only us and across the street a fallen French count [...]. (Cixous 1998a:

Frantz Fanon describes this segregation of urban space in colonial Algeria in Chapter 1 of Les Damnés de la terre ([1961] 2002).

15. Almost another animot, which Cixous barely exploits. Yet, the resonances of the German word Grille (grillon) become audible and turn the gates into another of 'her' voices, when the narrator at the end of Philippines notes: 'La voix des Grilles me touche, le mélange d'odeurs de geôle et d'oranger me grise, me monte à la tête (Cixous 2009: 95).

16. The expulsion led to a mesh of decisions and situations that would only heighten the experience of the dehumanizing effects of colonialism territory was foreclosed for her. And even when moving to France, she realizes that any arrival proper would be impossible, once landed in France 'I saw that I would never arrive in France' (Cixous 1998a: 226).

In many of Cixous's texts, it is the image of gates that has become the emblem of this limbo, of an included exclusion experienced in colonial Algeria. Still in the recent Philippines. Prédelles (2009) we hear a narrator who is strongly affected by experiences of closed gates and segregated neighbourhoods. ${ }^{14}$ Throughout Philippines - which takes its title from ' 54 , rue Philippe à Oran' (Cixous 2009: 16) where the Cixous family lived before moving to Algiers - the narrator is haunted by the image of gates: 'Les Grilles m'assignent à répondre. Me visent. Me touchent. Mes grilles de culture, de fantasme' (Cixous 2009: 60). And later: 'Le signe de mon destin. La Grille' (Cixous 2009: 93). Not only in Philippines, but also in many earlier texts, les Grilles ${ }^{15}$ are a key image of exclusion and of the dehumanizing reality of colonial segregation, whether they are the real gates surrounding the family's house in Algiers, or the invisible walls precluding any reciprocated bond with Drif. The image appears in her 'psychomythical' repertoire, as Cixous remembers in her preface to the collection Stigmata. Escaping Texts (1998), after her father, a lieutenantdoctor in the French army in Tunisia in 1939, was admitted in that function to the Cercle Militaire in Oran. It was 'a superb garden reserved for the class of officers' (1998b: xv) and the daughter rejoiced in being admitted. But only a year later, as a result of Vichy laws, Jews were excluded from it and for the daughter the 'bars rising to the sky and burrowing into the earth' (Cixous 1998b: xv) manifested for the first time a separation of 'humanity into two camps: the admitted and the non-admissible' (Cixous 1998b: xv). This scene, Cixous says, inflicted her 'first stigmata at the age of 3 exactly in the Garden' (Cixous 1998b: xiv) of the Cercle Militaire. As a consequence, she writes - evoking a corporeal wound similar to the fangmarks on her foot - 'I have the Cercle Militaire and its bars under my skin for eternity. Am I inside, am I outside?' (Cixous 1998b: xvi). ${ }^{16}$ She comes to realize that this event was not an incidental derailment of French politics, but a colonial principle: 'A typical phenomenon of colonization: closed circles, clubs, beaches, swimming pools. All reserved for the French. (Jews excluded)' (Cixous 1998a: 218). As we can read in Philippines, the gates as markers of colonial division and racialized segregation summoned a response - les Grilles m'assignent à répondre. From Dedans up until Philippines, Cixous produces precisely that: responses to these wounds, readings and examinations of these scenes, turning them every way to read their overly rich connotations and effects. And in these readings, she precisely performs the task of learning that forms the second axis of the 'human' for Cixous. The responses that are given to these scenes that affect us are ways to assure that one is able to become 'more' or 'better' human in the course of it.

I have taken 'Fips' and 'les Grilles' here as two exemplary images that Cixous scrutinizes in such a way. The particular conceptual response that she distilled from examining these colonial scenes from her childhood is, as I have been suggesting here, her doubled concept of the 'human': her insistence on the term 'human' to signal that we exceed closed off communities of all kinds, and her proposition to understand the term as a specific responsibility to producing grounds reflective of our entanglements and 
the least harmful possible to others. Again, Cixous's remark on Derrida in this regard can be taken equally as a remark on her own work: 'C'est depuis les Algéries, en Algérie, d'aporie en aporie qu’il élabore le Principe de toute sa vie profondément éthique: faire le moins de mal possible, être avec l'autre' (Cixous 2008a: 55).

\section{Nous sommes pleins de voix, comme toutes les îles}

In the conversation that has framed my argument here, Calle-Gruber observes that Cixous's employment of the term 'human' is an attempt to move away from its anthropocentric, as well as humanist implications, precisely in order not to give up on the term. And Cixous is indeed adamant about not letting go of it: "Il faut absolument ne pas lâcher le mot "humain". Il est si important' (Cixous and Calle-Gruber 1994: 40). However, in line with her investment in (re)writing our conceptual vocabulary in order to take our language and thinking into new directions - directions of protection and safeguarding rather than destruction, of life rather than of death $^{17}$ - she redeploys it in the ways we saw.

As I suggested, Cixous gives two vectors to the term 'human' and both are fundamentally at play in the exemplary figures that I have examined here: the dog and the gates. They are particularly intense images and rich scenes that Cixous incessantly returns to and reworks in her texts, whereby she performs readings of her 'world' in order to, as she says, 'play' it. What she learnt from this specific disorder of identity ${ }^{18}$ - from the marks left by teeth and gates engraved in body and mind - is that we as humans are fundamentally and continuously affected by others and thus always stay in passance, but are therefore also always called upon to 'fabricate a ground'. If our ground was merely given, there would be no need to fabricate it. Yet, since we are - due to being affected and by affecting others always exposed to change, transformation and passage, and woven from the many voices and traces that constitute each and every one of us, even if they often escape our notice, we are also bound to create our grounds, each and everyone of us, concretely and in a singular fashion. All the features of Cixous's thinking are gathered here: the fact that Cixous starts from our corporeal situatedness and affectivity as a shared characteristic of human and non-human life, which implies permanently porous surfaces and edges at which exchange and reverberations take place; the fact that she affirms passage, growth and movement before and beyond fixated categories and species; and the fact that the subjects of which she speaks are always diffracted 'I's' constituted by traces of a multiplicity of others. All of these features clearly show that to speak of fabricating a ground cannot mean to arrive or even aim at stability or permanence, at new demarcations of inclusion and exclusion, of neatly circumscribed and stable identities. Any ground is, under these predicaments, always an (un) ground, which necessarily stays in transformation and passance. 'Human' is precisely the term that permits Cixous both the refusal of being enclosed into segregated communities, clearly separated species, or sexes or cultures and the demand of a work of learning, of reading what we witness and undergo, whom we encounter and affect, and what touches us, in order to inhabit the world in ways that are less harmful to ourselves and others and more adequate to the diffracted and corporeal beings that we are. and anti-Semitism, a confluence of circumstances that is interesting in its own right for the generation of Cixous's thinking, but too ramified to be accounted for here. To only briefly mention three major aspects: (1) her father's belief that by moving to Algiers he would leave the antiSemitism experienced in Oran behind; (2) his choosing the ClosSalambier, thinking that his children would fare just as well in the borough as he and his wife; and (3) unawares, dying of tuberculosis, he chose the Lycée Fromentin for Hélène, 'ce prétendu lycée de filles qui depuis Vichy évite les juives, les juives allaient toutes à l'autre lycée' (Cixous 2000: 122). All of this conspired to a web of circumstances and affects 'grâce auquel mon âme a été formée' (Cixous 2000: $122-23)$.

17. When in H.C. pour la vie, c'est à dire ... (2000) Derrida discusses the proximity between his and Cixous's work, he distinguishes them along their different philosophical inclinations, noting Cixous's thinking as always interested in and turning towards life, while his work is concerned by an examination of death. Derrida calls it 'un grand différend entre nous, moi, qui me sens toujours tourné du côté de la mort, je ne suis pas de son côté, alors qu'elle voudrait tout tourner et faire venir du côté de la vie' (2000: 40). Cixous discusses the 
difference between her and Derrida's

thinking along the same lines in 'Entre Tiens' (cf. Cixous and Calle-Gruber 1994: 87-94); cf. also their conversation about the differences between them in $\mathrm{H}$. Cixous and J. Derrida (2004).

18. Both Cixous and Derrida speak of this condition of unbelonging, which forecloses any unambiguous belonging or any stable concurrence of 'who we are' with the territories we live on, as a sort of disorder. In Les Rêveries de la fermme sauvage, Cixous speaks in this respect of "cette sorte de maladie algérie que je faisais en Algérie ou qu'elle me faisait, cette sensation d'être possédée par une sensation de dépossession (2000: 16) (translated in the English version as 'Algerian disorder'), and Derrida, in $L e$ Monolinguisme de l'autre, speaks of the fact that '[ê]tre franco-maghrébin, l'être "comme moi", ce n'est pas, pas surtout, un surcroît ou une richesse d'identités, d'attributs ou de noms. Cela trahirait plutôt, d'abord, un trouble de l'identité' (1996:

32). Disorder, of course, not only also evokes the instability of 'identity', but also a medical condition with which one needs to learn to live, from which one needs to nevertheless derive one's singular ways of living.
The specific way in which Cixous performs the work of learning that such a dynamic demands of us is through writing. As we saw above, writing in Cixous's understanding and practice pays attention to the movement before fixation, to the in-between. As early as 'Le Rire de la Méduse', she notes that we need to affirm

qu'écrire c'est justement travailler (dans) l'entre, interroger le procès du même et de l'autre sans lequel rien ne vit [...] c'est d'abord vouloir le deux, et les deux, l'ensemble de l'un et l'autre [...] dynamisés à l'infini par un incessant échangement de l'un entre l'autre sujet différent.

(Cixous [1975] 2010a: 51-52)

As such, writing starts 'un devenir à plusieurs histoires se traversant les unes les autres' (Cixous [1975] 2010a: 49), listening to and reading the plurality of voices and environments that constitute, situate and drive the course of our lives and that defy being assembled to a clear-cut identity, but from which we nevertheless weave our singularly embedded and entangled knots of existences. It is a prolific weaving, 'un tissage immense' (Cixous and Calle-Gruber 1994: 64), which she traces meticulously for the singular case of her own memory, psyche and body, thereby performing a practice that - if read in all its implications - will allow us to rethink what it means to live as 'human', or rather what is at stake in becoming 'more human'. If we carefully distil the lesson from Cixous's writings from the practice or work of learning they perform and from the conceptual innovations they offer - we can begin taking into account the multifaceted, diffracted, passionate and arduous array of voices and figures that constitute each of us as 'I with a myriad of others' and trace new ways of thinking about what we mean by human subjectivity.

Making the 'human' a notion that designates both a shared whole beyond one's small house and the potential to grow and create in ways that are specific to one's environment and heritage, and hence enable one at the same time 'à habiter dans sa maison' (Cixous and Calle-Gruber 1994: 44), is a response to forms of colonial violence and exclusion. It is her endeavour to articulate our affective entanglements in ways that take the conception of subjectivity in new directions, beyond the binaries of self/other and into the production of corporeal and entangled lives that work with and learn from the traces of past - the debts we incur, the pain we suffer and inflict, the various forms of power we are subjected to and subject others to - in order to transform these traces into future emancipatory articulations and in order to create situated existences that strive for a growth and mean for each of us: 'gagner de la terre, fabriquer un sol' (Cixous and Calle-Gruber 1994: 105).

\section{References}

Ahluwalia, P. (2010), Out of Africa: Post-Structuralism's Colonial Roots, London and New York: Routledge.

Andermatt Conley, V. (1992), Hélène Cixous, New York/London: Harvester Wheatsheaf.

Barad, K. (2007), Meeting the Universe Halfway: Quantum Physics and the Entanglement of Matter and Meaning, Durham and London: Duke University Press. 
Blyth, Ian and Sellers, Susan (2004), Hélène Cixous: Live Theory, London and New York: Continuum.

Chérif, M. (2008), Islam and the West. A Conversation with Jacques Derrida (trans. Teresa Lavender Fagan), Chicago and London: Chicago University Press.

Cixous, H. ([1969] 1986), Dedans, Paris: Éditions des femmes. (1998a), 'My Algeriance, in other words: To depart not to arrive from Algeria', in H. Cixous (ed.), Stigmata. Escaping Texts, London and New York: Routledge, pp. 204-31.

- (1998b), 'Preface: On stigma texts by Hélène Cixous', in H. Cixous (ed.), Stigmata. Escaping Texts, London and New York: Routledge, pp. xi-xvi.

— (1998c), 'Stigmata, or Job the dog', in H. Cixous (ed.), Stigmata. Escaping Texts, London and New York: Routledge, pp. 243-61.

— (2000), Les Rêveries de la femme sauvage: scènes primitives, Paris: Éditions Galilée.

— (2003), 'Letter to Zohra Drif', College Literature, 30: 1, pp. 82-90.

_ (2008a), 'Celle qui ne se ferme pas', in M. Chérif (ed.), Derrida à Alger: Un Regard sur le Monde, Arles: Actes Sud, pp. 45-58.

- (2008b), in S. Sellers (ed.), White Ink. Interviews of Sex, Text and Politics, Stockfield: Acumen.

— (2009), Philippines. Prédelles, Paris: Éditions Galilée.

—_ ([1975] 2010a), 'Le Rire de la Méduse', in H. Cixous (ed.), Le Rire de la Méduse et autres ironies, Paris: Éditions Galilée.

—_ ([1975] 2010b), 'Sorties', in H. Cixous (ed.), Le Rire de la Méduse et autres ironies, Paris: Éditions Galilée.

Cixous, H. and Calle-Gruber, M. (1994), Hélène Cixous: Photos de Racines, Paris: Éditions des femmes.

Cixous, H. and Derrida, J. (2004), 'Du mot à la vie: un dialogue entre Jacques Derrida et Hélène Cixous', Magazine littéraire, 430: April, pp. 22-29.

Deleuze, G. (2004), 'Hélène Cixous, or writing in strobe', in G. Deleuze (ed.), Desert Islands and Other Texts: 1953-1974 (trans. M. Taormina), New York: Semiotext(e), pp. 230-31.

Derrida, J. (1996), Le Monolinguisme de l'autre; ou la prothèse d'origine, Paris: Éditions Galilée.

— (2000), H.C. pour la vie, c'est à dire ..., Paris: Éditions Galilée.

Fanon, F. ([1961] 2002), Les Damnés de la terre, Paris: La Découverte.

Goh, Irving (2010), 'The Passion According to Cixous: From Human Blindness to Animots', MLN, 125, pp. 1050-1074.

Hiddleston, J. (2010), Poststructuralism and Postcoloniality: The Anxiety of Theory, Liverpool: Liverpool University Press.

Kaiser, B. (2011), Figures of Simplicity: Sensation and Thinking in Kleist and Melville, Albany: Suny Press.

Memmi, A. ([1957] 1985), Portrait du colonisé: précédé du portrait du colonisateur, Paris: Gallimard.

Segarra, M. (2006), 'Helene Cixous's other animal: The half-sunken dog', New Literary History, 37, pp. 119-34.

Thiele, K. (2008), The Thought of Becoming: Gilles Deleuze's Poetics of Life, Zurich and Berlin: Diaphanes.

Young, R. (1990), White Mythologies: Writing History and the West, London/New York: Routledge. 


\section{Suggested citation}

Kaiser, B. M. (2012), '(Un)grounding the human: Affective entanglements and subjectivity in Hélène Cixous's Algerian reveries', International Journal of Francophone Studies 15: 3\&4, pp. 477-496, doi: 10.1386/ijfs.15.3\&4.477_1

\section{Contributor details}

Birgit Mara Kaiser is Assistant Professor at the Department of Comparative Literature at Utrecht University. Her primary research interests are literature and forms of sensate thinking, aesthetics and affectivity, and she currently works on diffracted singularities and affective subjectivity in a postcolonial world. She is the author of Figures of Simplicity: Sensation and Thinking in Kleist and Melville (Suny Press, 2011) and editor (with Lorna Burns) of Postcolonial Literatures and Deleuze: Colonial Pasts, Differential Futures (Palgrave MacMillan, 2012). She is currently editing (with Kathrin Thiele) a special issue of the journal Parallax entitled 'Diffracted Worlds - Diffractive Readings: Onto-Epistemologies and the Critical Humanities' (20/2, issue 72, July 2014).

Contact: Department of Comparative Literature, Faculty of Humanities, Utrecht University, Trans 10, 2.22b, 3512 JK Utrecht, the Netherlands.

E-mail: b.m.kaiser@uu.nl

Birgit Mara Kaiser has asserted her right under the Copyright, Designs and Patents Act, 1988, to be identified as the author of this work in the format that was submitted to Intellect Ltd. 
Copyright of International Journal of Francophone Studies is the property of Intellect Ltd. and its content may not be copied or emailed to multiple sites or posted to a listserv without the copyright holder's express written permission. However, users may print, download, or email articles for individual use. 